resources. It therefore selected narrower objectives, including transmissible tropical diseases, mother and child care, genetics, environmental hygiene and nutrition and tropical agriculture.

The European Parliament last month lambasted the Commission for the lack of consultation with the countries intended to benefit and the failure to coordinate plans with those of the World Health Organization (in tropical medicine) and the Consultative Group for International Agricultural Research.

The Parliament's view is that the programme takes too little account of the need for training in research, and of the need to develop career structures for scientists. The Parliament is especially critical of the way in which the Commission plans to spread its meagre resources thinly over too many projects.

The Parliament's criticisms are embodied in a report by one of its West German members, Renate Rabbethye. To the extent that the report advocates that Community spending on development assistance should not become a hidden subsidy for European institutes, the Parliament has made common cause with $\mathrm{Mr}$ Pisani. What will eventually happen to the Community's development research programme will depend also on the reaction of the commissioner for research, Vicomte Etienne Davignon, who is also said to favour a more generous programme.

Jasper Becker

\section{Pharmaceuticals in Bangladesh}

\section{Use less drugs}

The government of Bangladesh, in a move that has delighted voluntary agencies but upset many of the pharmaceutical companies operating there, has banned 1,742 drugs described as "harmful" or "unnecessary" as part of a wide-ranging new drug policy. On 12 June the Ministry of Health published a new Drug Ordinance, replacing the Drug Act of 1940 , which prohibits the sale of 237 " harmful" drugs with immediate effect and of 1,505 other "unnecessary" products which are to be withdrawn or reformulated within six months.

The new ordinance follows the advice of an Expert Committee on Drugs and Drugs Policy which met earlier this year under the chairmanship of Professor Nurul Islam. The committee's report was accepted by a council of advisers in May. The objective of the new drugs policy, according to the committee's report, is "to ensure the quality and availability of essential drugs which are of relevance to the health needs of the majority of the population"'. The report refers to the need for companies to concentrate on a limited list of 150 essential drugs as recommended by the World Health Organization. Limitations on national resources and the shortage of foreign exchange are given as reasons for the removal of "all unnecessary, useless drugs and drugs of doubtful efficacy".

Prominent on the banned list are tonics, cough linctuses and antibiotic tetracycline syrups such as Glaxo's Clinmycin syrup and Pfizer's Vibramycin syrup, stated to be harmful to the bony growth of children although tetracycline in capsule form may still be sold for adult use. Hoechst's Polytamin, a combination vitamin tonic which includes vitamin $\mathrm{B}_{12}$ and alcohol, is described as "one of the most abused drugs on the market"; and Squibb's Verdiviton Elixir is said to be "a highly misused, dangerous, habit-forming drug".

Also listed are antidiarrhoeal drugs already either banned or withdrawn from the market in the United States and European countries, such as Ciba-Geigy's Enterovioform and Mexaform tablets.

The government's initiative has been welcomed by voluntary health organizations in Bangladesh which have for several years drawn attention to the dangers of inappropriate drugs circulating in Bangladesh without doctor's prescriptions and at high cost. One organization, Gonoshasthaya Kendra (the People's Health Centre), which provides health services to a population of 100,000 at Savar, near Dacca, has even been manufacturing its own low-cost "essential" drugs as alternatives to the products of large companies. This venture is supported by Dutch and British voluntary agencies, including Oxfam and Christian Aid, which recently made a further grant of $£ 25,000$ towards its operating costs.

The more immediate impact of the new ordinance will be on the profitability of the 166 licensed manufacturing companies. About 75 per cent of the pharmaceutical market in Bangladesh is controlled by eight foreign-based companies, of which four are in Britain: Fisons, Glaxo, ICI and May \& Baker. According to the Consumer Association of Bangladesh, these four companies had a turnover in 1981 of 420 million taka (about $£ 10$ million). Twentyfive local companies supplied a further 15 per cent of the market.

The new drug policy will not easily be implemented. The smaller producers and exporters, as well as the medium-sized companies, are seriously threatened. At an emergency meeting in Dacca in June of the Bangladesh Aushad Shilpa Samity, an association of 33 pharmaceutical companies including six multinationals, it was claimed that local production of medicines would drop by 80 per cent if the new policy were implemented and that thousands of jobs would be sacrificed.

In a carefully-worded appeal to the Martial Law Authority published in Bangladesh newspapers, the Samity gave its "full support" to the review of drugs and medicines as part of the health-care system but went on to say that national rather than multinational companies could be hardest hit.

\section{Diderot's mantle for Chevènement?}

A "tremendous project" to launch an "encyclopaedia for the $21 \mathrm{st}$ century" is under way at the French ministry of research and industry. It springs from the enthusiasm of the minister, Jean-Pierre Chevènement, for bolstering French as a language of science.

So far, no details have been fixed, but other ministers have warmly approved a confidential report on the subject. In the National Assembly recently, Chevènement described the project as " a great cultural enterprise inspired by the encyclopaedia of Diderot and d'Alembert'". He reckons that the new encyclopaedia could be completed by 1989 - too late for the next presidential election.

Diderot and d'Alembert's encyclopaedia played an important role in the "Enlightenment", the period of unbounded faith in science and reason that Chevenement would dearly like to see reborn in the new France. More-

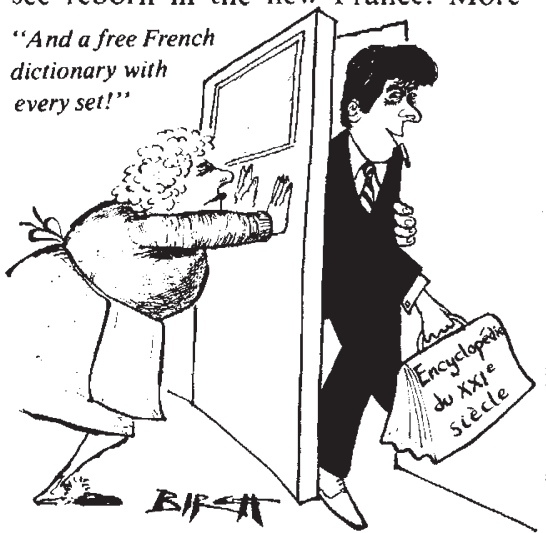

over, today an encyclopaedia need not appear only in print: "books, pamphlets, pictures, films, videotapes, videodisks, all the means of modern technology would be used to place at the disposition of France and all those who speak French ... the knowledge of humanity", the minister told the French deputies.

Although the encyclopaedia would be likely to concentrate on science, technology and the arts of manufacture, it would have a very open structure - where anyone who wanted to contribute could do so (subject to a degree of vetting by a committee of specialists). The objective, according to a spokesman for the ministerial information agency, MIDIST, which will coordinate the project, is to create a "living" encyclopaedia that would reflect many shades of opinion.

Questions of cost, manpower and other such practical matters have yet, however, to be answered. "All we have is the proposal and a political will to go forward" said the MIDIST spokesman. Robert Walgate 